\title{
META-ANALYSIS THE EFFECTIVENESS OF ZINC ON PNEUMONIA IN CHILDREN UNDER FIVE
}

\author{
Anastasia Dwi Anggraeni'), Bhisma Murti²), \\ Yulia Lanti Retno Dewi3) \\ 1)Masters Program in Public Health, Universitas Sebelas Maret \\ ${ }^{2)}$ Faculty of Medicine, Universitas Sebelas Maret
}

\begin{abstract}
Background: Zinc is an essential metal that is involved in the regulation of carbohydrate and lipid metabolism, immune system, and functioned the reproductive, cardiovascular, and nervous system. Recent clinical trials suggested that zinc supplementation given with empiric antimicrobial therapy can significantly shorten the duration of severe pneumonia, tachypnea, and hypoxia, in children with pneumonia. This study aimed to evaluate the effectiveness of zink uptake in pneumonia treatment in children under five.

Subjects and Method: This was a systematic and meta-analysis study conducted using PRISMA guideline. The articles published from 1998 to 2019 were collected from Pubmed, Science Direct, and Spinger Link databases. There were 5 randomized controlled trial studies that met the criteria. The study sample was children aged o to 6 years. As many as 3,731 children were divided into two groups, (1) 1,865 children who received zinc and (2) 1,879 children who received placebo. The dependent variable was pneumonia. The independent variable was zinc. The data were quantitatively analyzed using Review Manager (RevMan) 5.3 software.

Results: There is high heterogeneity between experiments $\left(I^{2}=92 \% ; p<0.001\right)$, so this study used the Random Effects Model (REM). Zinc elevated recovery from pneumonia 0.58 days sooner than placebo $(\mathrm{MD}=-0.58 ; 95 \% \mathrm{CI}=-0.32$ to -1.04$)$.

Conclusion: Zinc elevates recovery from pneumonia 0.58 days sooner than placebo.
\end{abstract}

Keywords: zinc, pneumonia, children under five

\section{Correspondence:}

Anastasia Dwi Anggraeni. Masters Program in Public Health, Universitas Sebelas Maret. Jl. Ir. Sutami 36A, Surakarta 57126, Central Java. Email: anastasia1702@student.uns.ac.id. Mobile:+6282269344444. 